Louisiana State University

LSU Digital Commons

Faculty Publications

Department of Oceanography \& Coastal

Sciences

2007

\title{
Managing Coastal Resources In The 21St Century
}

M P. Weinstein

mweinstein@njmsc.org

R C. Baird

D O. Conover

M Gross

M P. Weinstein

See next page for additional authors

Follow this and additional works at: https://digitalcommons.Isu.edu/oceanography_coastal_pubs

\section{Recommended Citation}

Weinstein, M. P., Baird, R. C., Conover, D. O., Gross, M., Weinstein, M. P., Loomis, D. K., Naveh, Z., Peterson, S. B., Reed, D. J., Roe, E., Swanson, R. L., Swart, J. A., Teal, J. M., Turner, R., van, d. e., \& Windt, H. J. (2007). Managing Coastal Resources In The 21St Century. Frontiers In Ecology And The Environment, 5 (1), 43-48. https://doi.org/10.1890/1540-9295(2007)5[43:MCRITS]2.0.CO;2

This Article is brought to you for free and open access by the Department of Oceanography \& Coastal Sciences at LSU Digital Commons. It has been accepted for inclusion in Faculty Publications by an authorized administrator of LSU Digital Commons. For more information, please contact ir@lsu.edu. 


\section{Authors}

M P. Weinstein, R C. Baird, D O. Conover, M Gross, M P. Weinstein, D K. Loomis, Z Naveh, S B. Peterson, D J. Reed, E Roe, R L. Swanson, J A. Swart, J M. Teal, R. Eugene Turner, d e. van, and H J. Windt 
See discussions, stats, and author profiles for this publication at: https://www.researchgate.net/publication/33548496

\section{Managing coastal resources in the 21st century}

Article $\cdot$ January 2007

Source: OAl

CITATIONS

80

16 authors, including:

Michael P. Weinstein

New Jersey Marine Sciences Consortium (Retired)

231 PUBLICATIONS 6,672 CITATIONS

SEE PROFILE

Jozef Keulartz

Wageningen University \& Research

245 PUBLICATIONS 1,619 CITATIONS

SEE PROFILE
READS

504

David O. Conover

Stony Brook University

153 PUBLICATIONS 15,400 CITATIONS

SEE PROFILE

David K Loomis

East Carolina University

46 PUBLICATIONS 1,273 CITATIONS

SEE PROFILE

Some of the authors of this publication are also working on these related projects:

Coastal Marine Recreation at Dry Tortugas National Park: Understanding the Ecological Attitudes, Behavior, and Knowledge of Park Visitors View project 


\title{
Managing coastal resources in the $21 \mathrm{st}$ century
}

\author{
Michael P Weinstein ${ }^{1 *}$, Ronald C Baird ${ }^{2}$, David O Conover ${ }^{3}$, Matthias Gross ${ }^{4}$, Jozef Keulartz ${ }^{5}$, David K Loomis ${ }^{6}$, \\ Zev Naveh ${ }^{7}$, Susan B Peterson ${ }^{8}$, Denise J Reed ${ }^{9}$, Emery Roe $^{10}$, R Lawrence Swanson ${ }^{3}$, Jacques AA Swart ${ }^{11}$, \\ John M Teal ${ }^{12}$, R Eugene Turner ${ }^{13}$, and Henny J van der Windt ${ }^{11}$
}

\begin{abstract}
Coastal ecosystems are increasingly dominated by humans. Consequently, the human dimensions of sustainability science have become an integral part of emerging coastal governance and management practices. But if we are to avoid the harsh lessons of land management, coastal decision makers must recognize that humans are one of the more coastally dependent species in the biosphere. Management responses must therefore confront both the temporal urgency and the very real compromises and sacrifices that will be necessary to achieve a sustainable coastal ecosystem, one that is economically feasible, socially just, and ecologically sound.
\end{abstract}

Front Ecol Environ 2007; 5(1): 43-48

$\mathrm{T}$ he public trust doctrine and the right to ownership of coastal lands are rooted in early human civilization and appear to be important factors in the establishment

\section{In a nutshell:}

- Humans are disproportionately dependent on the world's coasts for living space, extractable commodities, and economic growth. As a consequence, how people and other coastal biota share space and resources becomes the great challenge of the 21st century

- Conflict mitigation, consensus building, trade-offs, sacrifice, and compromise will become the norm for sustainable coastal management

- A sustainable future will also depend on mankind's ability to adopt a transdisciplinary approach to both ecology and commerce management of coastal resources proportional to human dominance in the landscape

${ }^{1}$ New Jersey Marine Science Consortium, Sandy Hook, NJ 07732 *(mweinstein@njmsc.org); ${ }^{2}$ Center for Marine Science, University of North Carolina-Wilmington, Wilmington, NC 28409; ${ }^{3}$ Marine Sciences Research Center, Stony Brook University, Stony Brook, NY 11794-5000; ${ }^{4}$ Department of Urban and Environmental Sociology, UFZ, Centre for Environmental Research, Leipzig, Germany; ${ }^{5}$ Department of Applied Philosophy, Wageningen University $\mathbb{8}$ Research Centre, The Netherlands; ${ }^{6}$ Human Dimensions Research Unit, Department of Natural Resources Conservation, University of Massachusetts-Amherst, Amherst, MA, 01003; ${ }^{7}$ Faculty of Civil and Environmental Engineering, Technion, Haifa 32000, Israel; ${ }^{8}$ Teal Partners, Rochester, MA 02770; ${ }^{9}$ University of New Orleans, New Orleans, LA 70148; ${ }^{10}$ Department of Public Affairs and Administration, California State University-East Bay, Hayward, CA 94542; ${ }^{11}$ Science 8 Society Group, Biological Centre, University of Groningen, The Netherlands; ${ }^{12}$ Department of Biology, Woods Hole Oceanographic Institution, Woods Hole, MA 02543; ${ }^{13}$ Coastal Ecology Institute, Louisiana State University, Baton Rouge, LA 70803 of the world's most successful economies (Gallup et al. 1999; Weinstein 2005):

"And truly by natural right, these be common to all; the air, running water, and the sea, and hence the shores of the sea. Also all rivers and ports are public, so that the right of fishing in a port and in rivers is common to all. And by the law of nations the use of the shore is also public, and in the same manner as the sea itself...Any person is at liberty to place on [the shoreline] a cottage, to which he may retreat, or to dry his nets there, and haul them from the sea... The right of fishing in the sea from the shore belongs to all men...Everyone has a right to build on the shore, or by piles upon the sea, and retain the ownership of the construction so long as it lasts, but when it falls into ruins, the soil reverts to its former status..."

Roman Civil Law, Institutes of Justinian, Liber 2, Tract 1, Section 1

As a consequence, humans have become disproportionately dependent on the coastal zone for living space and recreation, extractable commodities, ports and harbors, commerce and the military, wastewater disposal, sites for power production and distribution, and for industrial water supply (Schubel and Hirschberg 1978; Figure 1). The rapid acceleration of these dependencies, for example in port expansion and coastal land development, have made managing coastal resources for the public good more challenging than at any time in the past.

Demographic shifts and new patterns of settlement place unprecedented pressures on human well-being and coastal ecosystem functions and stability, even as water- 


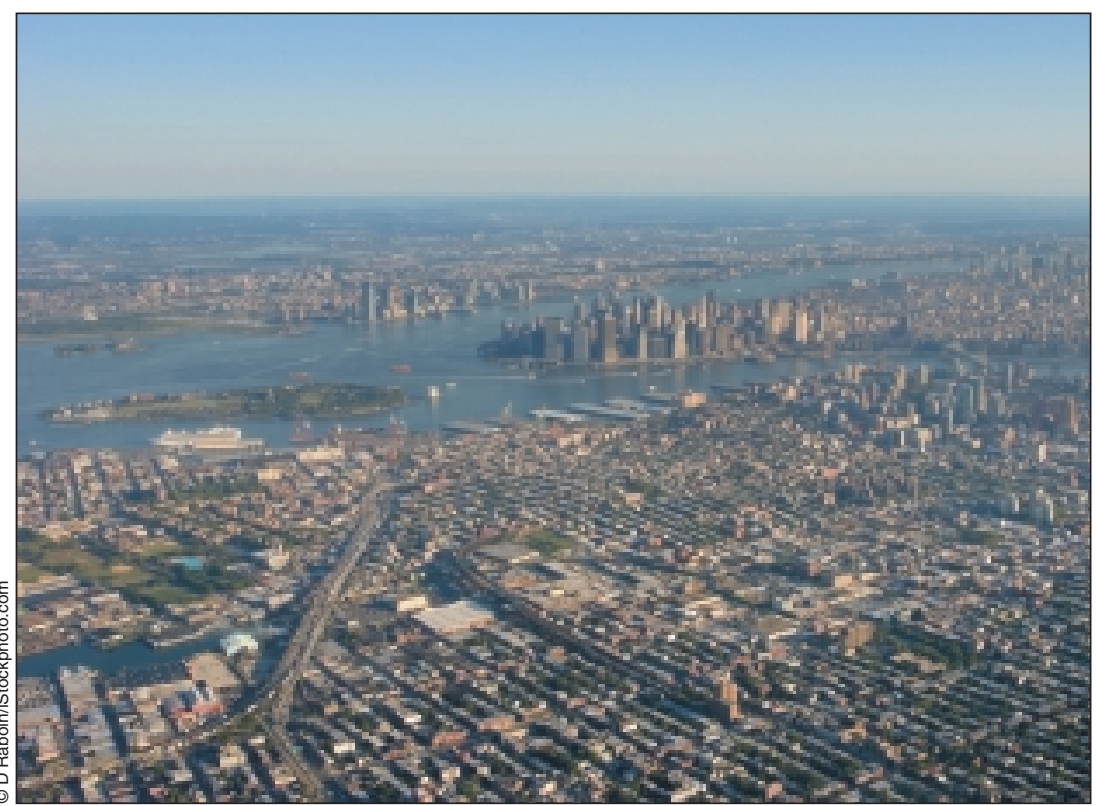

Figure 1. New Jersey-New York Harbor, with its attendant ports, commerce, intermodal transportation, and other human activities, is a classic example of mankind's dependence on the coastal zone.

borne trade, sea farming, and the effects of climate change accelerate (Figure 2). Society has yet to adequately address the challenge of coastal resource management in today's world, ie by facing changes that make sustainability more feasible technologically, but at the same time more difficult politically and economically. First, there has been a dramatic growth in per capita domestic product in many regions of the globe and an increased ability to meet human needs. Second, despite recent successes in decreasing harmful consumption per unit value of product, worldwide consumption of energy and other natural resources in industrialized nations continues to accelerate (Kates and Parris 2003).

Blue-ribbon panels and other authorities worldwide have called for the prioritization of uses in order to minimize conflicts, protect resources, and ensure that all uses are compatible with sustainability goals (US Commission on Ocean Policy 2004). The public interest is addressed through recommendations to balance long- and shortterm strategies with greater decentralization of governance to regional and local levels. Ecosystem-based management has been widely advocated as a central organizing principle for addressing coastal impacts holistically and reconciling multiple use conflicts at different geographic scales.

Nevertheless, academia, governance organizations, decision makers, and the general public have yet to confront one very real issue:

"Where multiple desirable but competing objectives exist, it is not possible to maximize each... [and] in any system with multiple competing objectives, it will not be possible to meet every one."

US Commission on Ocean Policy 2004
We believe the solution to resolving the emerging conflicts that will arise on the path to long-term sustainability will, in part, require the continued development and refinement of a number of concepts.

\section{Toward sustainability}

\section{The dual mandate and the resolution of conflict}

Whereas complexity, interdependence, high levels of uncertainty, unpredictability, and dynamism characterize natural systems - traits that prevent competitive dominance by any one species - human-dominated systems require predictability and stability to ensure uninterrupted provision of resources for human use. The paradox of the dual mandate arises from the need to reconcile society's desire to preserve, restore, and rehabilitate natural ecosystems while at the same time ensuring the provision of reliable, predictable, and stable supplies of goods and services at a time of escalating demand (Roe and van Eeten 2001).

\section{The emergence of sustainability science}

By focusing on the science-policy interface, sustainability science addresses the fundamental character of interactions between nature and society, and society's capacity to guide those interactions along sustainable trajectories (Kates et al. 2001). Globally, sustainable development policy reflects a largely political and social agenda. The natural sciences have often been relegated to a limited role in governance, and ignorance of basic ecological principles has led decision makers to make erroneous judgments. The underlying principles of sustainability science suggest that a sustainable biosphere is not only necessary but economically feasible, socially just, and ecologically sound. It targets the need to break down artificial and outdated disciplinary gaps between the natural and social sciences through the creation of transdisciplinary knowledge and its practical application to decision making.

Lubchenco (1998) provides an emerging role for science in today's society that applies new scientific knowledge to inform policy and management. Under this new social contract, the natural science and technology communities would devote a larger portion of their research and development agenda to addressing societal goals for sustainable development. We think that there are logical consequences of this view: (1) any new contract between science and society requires better translation of scientific results into information that can be readily understood by the public; (2) the public must be willing to, and must be given the opportunity to, participate in the production and 
use of knowledge relevant to shaping their lives, communities, and environments; and (3) scientists must be willing to reinforce the message that despite present uncertainties, decisions can and must be made without awaiting the results of further research. Additionally, adaptive management protocols will be increasingly important in accommodating new knowledge to the policy domain. Success also requires rethinking of the basic epistemological contexts of the scientific enterprise, perhaps as an extended forum in the process of decision making and knowledge production. New applications of science that incorporate different perspectives of society become more relevant and, in turn, contribute to more transparent and democratic processes of governance (Gibbons et al. 1994; Nowotny et al. 2001; Swart and van der Windt 2005).

\section{The human dimensions of natural resource management}

There is a growing awareness that the intractability of environmental problems can be explained in part by the social context in which they arise. When perceptions of a problem vary broadly, and when there is uncertainty in the scientific assumptions and outcomes that underlie the process, consensus is difficult to achieve. Under such circumstances, tensions can arise among stakeholders, even when all are committed to sustainable development. This understanding of the social character of environmental problems has focused the attention of researchers, stakeholders, and policy makers on the important role of governance, participation, and collaborative decision making in better managing, if not solving, environmental problems.

The human dimensions of natural resource management incorporate the ways people affect, value, utilize, and benefit from coastal ecosystems ( $\mathrm{Sal} z$ and Loomis 2005). While ecological considerations are essential, the successful implementation of sustainable coastal management depends on, and is driven by, societal values. We need a better understanding of the human-induced causes and social drivers of environmental change and how human behavior can be made to coincide with environmental and social priorities. Although political, economic, and social systems make up the human dimensions of natural resource management, natural resource values originate in only the social system (Kennedy and Thomas 1995; Ayensu et al. 2003). These values are manifested as environmental laws, congressional budgets, volunteering, voting behavior, and management decisions, and largely determine the fate of the natural systems that sustain societies.

Implicit in the human dimensions approach is not whether ecosystems will persist - they will - but rather what tradeoffs will be struck and what kinds of ecosystems will be desired by individual social groups, based on their demographics, cultural identity, and existing and expected resource requirements. The present scenario is one in which issues tend to be treated in isolation, instead of being considered as part of an integrated ecosystem, and broad-scale decisions are generally avoided. Marine ecosystem management will continue to suffer if managerial and political measures (eg ocean zoning, fishing quotas) do not incorporate appropriate spatial and temporal scales of essential ecological processes: migration, dispersion, recruitment, etc (Cash and Moser 2000; Berkes 2006). Accordingly, policy makers may too easily avoid the tradeoffs and there are therefore manyconflicts and few solutions.

\section{Integrated coastal zone management, ecosystem- based management, and ocean zoning}

Conflict mitigation, consensus building, trade-offs, sacrifice, and compromise will become the norm for sustainable coastal management, because growing demands on coastal resources can no longer be met by access to unexploited resources. An integrated systems approach is required, taking into account conflicting goals and interlinkages among environmental issues (Ayensu et al. 2003; Naveh 2005), as well as the geographic scales of both the issues and political jurisdictions. Integrated coastal zone 


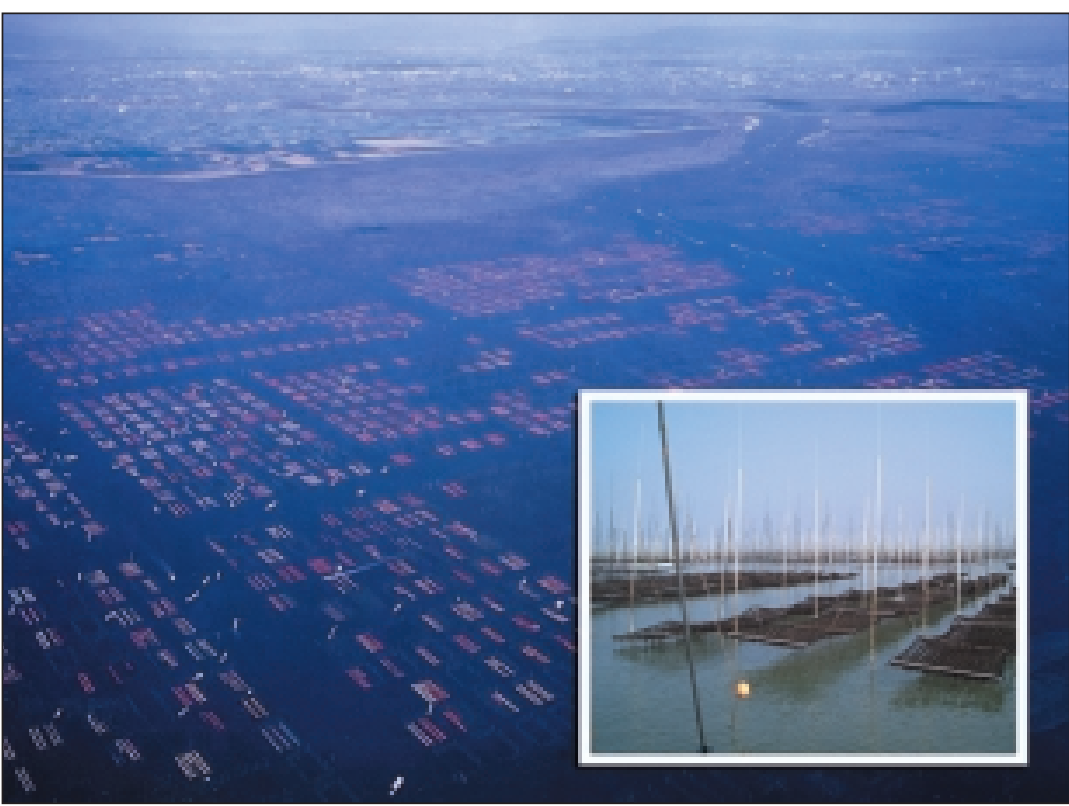

Figure 3. Approximately 20\% of the surface area of Ariake Sound, Japan is currently in nori (edible red algae) culture, a figure that will potentially double by the end of the century. Recent land reclamation and water diversion schemes in the inner Sound have negatively affected aquaculture and shell fisheries, establishing new conflicts among "sea farming" and other human uses.

management (ICZM) addresses these issues by considering the broader "problem-shed" (the area that encompasses all of the affected stakeholders), and is designed to manage competing uses (Figure 3). Its success depends on the ability to create new paradigms that will resolve the growing tensions among the involved communities.

More effort at the interface between science and society is needed in order to make the transition from the centralized, top-down approach of government institutions to more decentralized, regional, and local approaches to resource management (Bruckmeier 2005). New policies for knowledge production and dissemination in which multiple stakeholder groups are involved are critical to this approach. Bruckmeier (2005) also suggests that "soft factors" such as the values, attitudes, interests, and aspirations of stakeholders should be incorporated into the development process. If these are neglected in the formal and legal rules systems, escalation of existing conflicts may ensue. Because of the multidimensional nature of these conflicts - their normative framework, complex knowledge basis, and the amalgam of empirical knowledge - the task will not be easy, but progress is being made with current efforts at ecosystem-based management (EBM). Managing competing uses also requires a transdisciplinary and systems approach, including biology, oceanography, anthropology, engineering, economics, agriculture, government, and law (Naveh 2005).

The US Commission on Ocean Policy (2004) called for just such a balance between ecological, environmental, and social influences through an ecosystem-based approach (Figure 4). Their report recognized that "ocean policies cannot manage one activity, or part of the system, without considering its connections with all the other parts". EBM focuses on multiple activities within specific areas defined by ecosystem rather than political boundaries. It also places humans in the landscape, within the broader context of the biological and physical environment, and ultimately combines ecology and human dimensions into "society-integrated" or transdisciplinary ecosystem management (CBD 1993; Naveh 2002, 2005). Scientific understanding of both ecosystem processes and of the underlying role of variability in maintaining ecosystem resiliency (that might otherwise descend irreversibly into degraded states; Holling 2000) has improved in the past several decades. As a result, emerging management approaches can begin to conform more closely to ecological and societal values rather than being driven by purely political constraints.

Ocean zoning - the regulation (and allocation) of access to and use of specific marine geographic areas to help protect the environment, support economic development, and create equitable access to the ocean - is necessary for the successful management of coastal resources and watersheds. Crowder et al. (2006) believe that a reform of governance, just one aspect of ICZM, is necessary to truly implement zoning, as proposed for the California Channel Islands. Importantly, regulation of the oceans as a public resource must be based on integrated social, economic, ecological, and physical assessments of the ocean surface, as well as the air above it, the water column, and the seabed (Courtney and Wiggen 2003; Young 2006). While ICZM uses ocean zoning as an important tool, it is not by itself a panacea, because these multiple dimensions can support various objectives simultaneously or alternately. Effective implementation of such zoning within an integrated management framework requires commitment by all the relevant stakeholders (including sovereign nations), a task not easily achieved when different visions of sustainability are involved (Swart and van der Windt 2005).

\section{Difficult choices}

Conflict resolution in human-dominated ecosystems could also be improved by bandwidth management (ie managing performance fluctuations), gaming exercises, integrated power modeling, and by taking advantage of the tight coupling and complex interactions between large-scale technical systems and ecosystems that drive the high-reliability performance of both types of systems (Roe et al. 2005). Yet the sum of small, correct decisions 
made now are almost certainly better than dealing with the aftermath of catastrophic decisions later (eg the impacts associated with inadequate flood protection and the events that occurred following Hurricane Katrina in New Orleans).

Most citizens recognize that coastal resources are not inexhaustible, and the international call for fundamental shifts in ocean governance, political will, and coastal resource management is underway. The challenges we face in the move towards global sustainability are substantial and often under appreciated:

(1) The complexity of natural systems precludes a reductionist experimental approach to management. Moreover, the scale of large ecosystems make

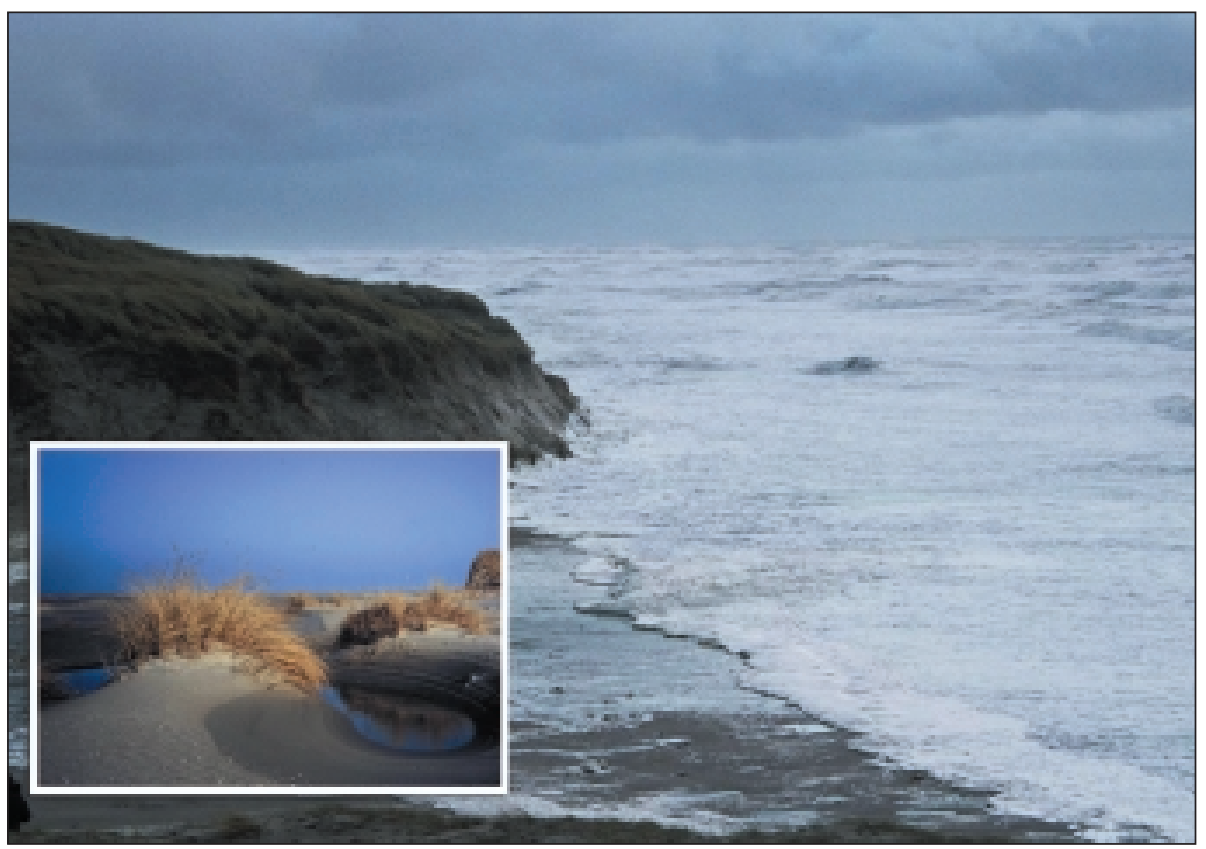

Figure 4. An ecosystem-based management (EBM) and ocean zoning approach to managing coastal resources may help preserve and conserve ecosystems relatively uninfluenced by human activities, such as in this region of the Dutch Wadden Sea. controlled and replicated experiments virtually impossible. Consequently, our "imperfect science" and the effects of natural variability and uncertainty lead to an inability to reach consensus and accurately predict the environmental consequences of our actions. We are often left with a wide range of opinions on the issues (Ludwig et al. 1993).

(2) With acquired wealth comes political and social power that is often used to promote further unlimited exploitation of natural resources (Ludwig et al. 1993).

(3) Traditional demography and economics do not incorporate sufficient appreciation of environmental principles. Furthermore, ecologists tend to disregard human influence and instead concentrate on ecosystem function and dynamics. Numerous authors have suggested that the failure to agree on a collective vision of how to attain sustainability lies in the limitations and disconnects among disciplines (Kaufman and Cleveland 1995; Holling 2000; Clark and Dickson 2003; McMichael et al. 2003; Naveh 2005).

(4) Anthropocentrism and the "we versus them" mentality stemming from the "arrogance of humanism" is a concept that expresses humankind's faith in its technology to manage nature so that all can prosper (Ehrenfeld 1981). In anthropocentric terms, humans have the "right" to control the natural world for the benefit of humanity.

Even a cursory examination of the published literature reveals the sometimes large divide between ecocentrists and anthropocentrists, scholars and practicioners, functionalists and compositionalists (Callicott et al. 1999), environmental organizations and industry, commercial and recreational fishermen, public and government, etc (Weinstein and Reed 2005). Thus, the ultimate compromises and sacrifices required - a distasteful concept to many, and possibly the root cause of the "we versus them" mentality that pervades environmental management - will be necessary to accommodate human needs in the coastal zone. Achieving a reasonable balance in meeting the demands of competing uses is the greatest challenge we face.

Acknowledging the magnitude of these problems, however, does not mean that we are unable to assert any control over our future. Human-dominated ecosystems have natural baselines that have permanently shifted, and resolving the paradox of the dual mandate should be redirected towards goals that rehabilitate ecological functions with the inevitable need for human service reliability (Roe et al. 2005). Otherwise, societal support for ecosystem-based management will erode away. Critical to any new approach is the realization that management goals should include elements of both ecology management and commerce management, proportional to human dominance in the landscape (Weinstein and Reed 2005). In the end, the successful transition to ecosystem-based management rests on a complex infrastructure that translates science-based information into public policy. This, in turn, elicits effective responses from society at large (Baird 2005). It is the performance and long-term capacity of this diverse array of entities (including scientific and educational institutions) from global to local scales that will ultimately determine the tempo and mode of transition to sustainability. Our fate rests in societal action involving all stakeholders, consensus building, and accepting 
the compromises and sacrifices that will ensure environmental and social justice for all.

\section{Acknowledgements}

The authors of this paper, the International Working Group on Sustainability, thank the many colleagues who participated in both individual and collective discussions leading to the framework for this paper. However, the composition of concepts and ideas presented herein are solely our own and should be addressed as such. Permission to use Figure 2 was gratefully provided by J Yanson and JN Cookson. This is contribution NJSG 05595 of the New Jersey Sea Grant College Program.

\section{References}

Ayensu E, van R Claasen D, Collins M, et al. 2003. International ecosystem assessment. Science 286: 685-89.

Baird RC. 2005. The human dimension in ecosystem management: institutional performance of the Sea Grant paradigm. In: Hennessey $\mathrm{T}$ and Sutinen J (Eds). Sustaining large marine ecosystems: the human dimension. New York, NY: Elsevier.

Berkes F. 2006. From community-based resource management to complex systems: the scale issue and marine commons. Ecol Soc 11: 45.

Bruckmeier K. 2005. Interdisciplinary conflict analysis and conflict mitigation in local resource management. Ambio 34: 65-73.

Callicott JB, Crowder, LR, and Mumford, K. 1999. Current normative concepts in conservation. Conserv Biol 13: 22-25

Cash WD and Moser SC. 2000. Linking global and local scales: designing dynamic assessment and management processes. Global Environ Change 10: 109-20.

Clark WC and Dickson NM. 2003. Sustainability science: the emerging research program. P Natl Acad Sci 100: 8059-61.

CBD (Convention on Biological Diversity). 1993. Handbook of the convention on biological diversity. 2nd edn. Montreal, Canada: Transcontinental Printing.

Courtney J and Wiggen J. 2003. Ocean zoning for the Gulf of Maine: a background paper. Boscawen, NH: Gulf of Maine Council on the Marine Environment.

Crowder LB, Osherenko G, Young OR, et al. 2006. Resolving mismatches in US ocean governance. Science 313: 617-18.

Ehrenfeld DW. 1981. The arrogance of humanism. New York, NY: Oxford University Press.

Gallup JL, Sachs JD, and Mellinger AD. 1999. Geography and economic development. Int Regional Sci Rev 22: 179-88.

Gibbons M, Limoges C, Nowotny H, et al. 1994. The new production of knowledge: the dynamics of science and research in contemporary societies. London, UK: Sage.

Holling CS. 2000. Theories for sustainable futures. Conserv Ecol 4: 7-13.

Kates RW, Clark WC, Corell R, et al. 2001. Sustainability science. Science 292: 641-42.

Kates RW and Parris TM. 2003. Long-term trends and a sustainability transition. P Natl Acad Sci 100: 8062-67.
Kaufman RK and Cleveland CJ. 1995. Measuring sustainability: needed - an interdisciplinary approach to an interdisciplinary concept. Ecol Econ 15: 109-12.

Kennedy JJ and Thomas JW. 1995. Managing natural resources as social value. In: Knight RL and Bates SF (Eds). A new century for natural resource management. Washington, DC: Island Press.

Lubchenco L. 1998. Entering the century of the environment: a new social contract for science. Science 279: 491-97.

Ludwig D, Hillborn R, and Walters C. 1993. Uncertainty, resource exploitation, and conservation: lessons from history. Science 260: 17-18.

McMichael AJ, Butler CD, and Folke C. 2003. New visions for addressing sustainability. Science 302: 1919-29.

Naveh Z. 2002. A transdisciplinary education program for regional sustainable development. Int J Ecol Environ Sci 28: 167-91.

Naveh Z. 2005. Epilogue: towards a transdisciplinary science of ecological and cultural landscape restoration. Rest Ecol 13: 228-34.

Nowotny H, Scott P, and Gibbons M. 2001. Re-thinking science: knowledge and the public in an age of uncertainty. Cambridge, UK: Polity Press.

Pew Oceans Commission. 2003. America's living oceans: charting a course for sea change. Washington, DC: Pew Oceans Commission.

Roe E, Schulman P, van Eeten M, and de Bruinje M. 2005. Highreliability bandwidth management in large technical systems: findings and implications of two case studies. J Publ Adm Res Theor 15: 263-80.

Roe E and van Eeten M. 2001. Threshold-based resource management: a framework for comprehensive ecosystem management. Environ Manage 27: 195-214.

Salz RJ and Loomis DK. Human dimensions of coastal restoration. In: Thayer GW, McTigue TA, Salz RJ, et al. (Eds). Sciencebased restoration monitoring of coastal habitats. Silver Spring, MD: NOAA.

Schubel JR and Hirschberg DJ. 1978. Estuarine graveyards, climate change, and the importance of the estuarine environment. In: Wiley M (Ed). Estuarine interactions. New York, NY: Academic Press.

Swart JAA and van der Windt HJ. 2005. Visions of nature and environmental sustainability: shellfish harvesting in the Dutch Wadden Sea. Restor Ecol 13: 183-92.

US Commission on Ocean Policy. 2004. An ocean blueprint for the 21st century. Final report. Washington, DC: US Commission on Ocean Policy.

Weinstein MP. 2005. Managing coastal growth in the 21st century: sustainability science and the paradox of the dual mandate. In: Feng H, Yu L, Solecki W (Eds). Urban dimensions of environmental change: science, exposure, police, and technologies. Monmouth Junction, NJ: Science Press.

Weinstein MP and Reed DJ. 2005. Sustainable coastal development: the dual mandate and a recommendation for "commerce managed areas". Rest Ecol 13: 174-82.

Young S. 2006. Would ocean zoning be an effective ocean management tool for the waters off Massachusetts? Vermont J Environ Law 7: 1-19 